\title{
SASTRA ANAK DAN PEMBENTUKAN KARAKTER
}

\author{
Burhan Nurgiyantoro
}

FBS Universitas Negeri Yogyakarta (e-mail: burhan@uny.ac.id)

\begin{abstract}
Children's Literature and Character Building. This article aims to describe roles and strategies of the learning of children's literature in character education. In terms of the materials, literature has already contained "raw materials" to build children's character. Literature is culture in action containing life models. The concept of people with ideal character highly appreciating morality and great values is concretely manifested in the story characters' attitudes and behaviors. Children can imitate the heroes with ideal norms and take their attitudes and behaviors as examples. Moreover, at their age, children like to imitate behaviors of people that they admire. To prevent literature learning from becoming rote learning, teachers and parents should work in synergy to help children read, understand, and give examples of concrete attitudes and behaviors so that the internalization process takes place. Therefore, story-telling activities for children should be routinely conducted and reading habits should be inculcated since the early age.
\end{abstract}

Keywords: children's literature, character building, culture in behaviors

\section{PENDAHULUAN}

Ketika di hadapan kita tersaji berita carut-marutnya kehidupan berbangsa ini yang tiada habis-habisnya, baik lewat pemberitaan televisi, internet, surat kabar, maupun media massa yang lain, kita mungkin setuju bahwa keadaan itu semua lebih disebabkan oleh kurang mengenanya pendidikan karakter anak bangsa. Lembaga pendidikan yang seharusnya berada di ujung tombak selaku penjaga ketangguhan karakter, bahkan tidak jarang menampilkan sosok yang lebih mencerminkan kurangnya status berkarakter itu. Bocornya soal ujian nasional di berbagai pelosok tanah air, usaha guru dan peserta didik untuk menempuh segala cara asal lulus, kasus plagiat yang baru saja membelalakkan mata yang menimpa guru besar (kasus Unpar) dan doktor (kasus ITB), dan berbagai kasus lainnya seolah-olah memerkuat dugaan tersebut. Hal itu belum lagi berbagai kasus yang kini menimpa para pelaku kerah putih seperti kejahatan makelar kasus perpajakan dan perbankan.

Sebenarnya masalah-masalah kurang baik yang terkait dengan karakter tersebut bukan hanya dialami oleh bangsa Indonesia, melainkan juga bangsa-bangsa lain di dunia. Maka, tidak berlebihan jika masalah pendidikan karakter untuk membentuk karakter merupakan masalah universal. Hanya saja belum tentu ada keseragaman 
tentang pandangan bagaimana karakter yang baik yang diidealkan karena hal itu juga tidak lepas dari pandangan hidup suatu bangsa. Hal itu tampaknya terkait dengan masalah pandangan moral, pandangan tentang baik dan buruk, tentang benar dan salah, yang juga belum tentu sama di antara berbagai bangsa. Padahal, pandangan tentang moral merupakan pondasi yang penting bagi pembentukan karakter. Namun, untuk memeroleh sebutan sebagai orang berkarakter sebenarnya lebih dari sekadar bermoral karena sebutan menjadi berkarakter memiliki tuntutan dan makna yang lebih tinggi.

Pendidikan karakter dimaksudkan sekaligus sebagai pembentukan karakter. Usaha pendidikan dan pembentukan karakter yang dimaksud tidak terlepas dari pendidikan dan penanaman moral atau nilai-nilai kepada peserta didik. Pendidikan karakter itu sendiri merupakan sebuah proses panjang, yaitu proses pembelajaran untuk menanamkan nilai-nilai luhur, budi pekerti, akhlak mulia yang berakar pada ajaran agama, adat-istiadat dan nilai-nilai keindonesiaan dalam rangka mengembangkan kepribadian peserta didik supaya menjadi manusia yang bermatabat, menjadi warga bangsa yang berkarakter sesuai dengan nilai-nilai luhur bangsa dan agama (Sardiman, 2009:76). Dari sini dapat dipahami bahwa pendidikan karakter memfokus pada pendidikan nilai-nilai luhur dengan sekian jumlah variannya. Tujuan pendidikan karakter adalah agar peserta didik menjadi orang yang bermatabat, orang yang berkarakter dalam arti yang sebenarnya, dan bukan sekadar hafal secara kognitif apa itu pendidikan karakter dan ciri orang yang berkarakter.

Orang pasti sependapat bahwa ada banyak cara dan "bahan" yang dapat dikreasikan untuk mendidik, memupuk dan mengembangkan, serta membentuk karakter peserta didik. Cara yang dimaksudkan adalah proses dan strategi, sedang "bahan" adalah bahan ajar (baca: mata pelajaran, pokok bahasan) yang dapat dimuati usaha pendidikan karakter. Pendidikan karakter dalam usaha pembentukan karakter tidak diajarkan secara mandiri sebagai sebuah bahan ajar sebagaimana halnya matamata pelajaran yang lain, melainkan termuat dan diikutsertakan dalam pembelajaran berbagai mata pelajaran tersebut baik dalam proses dan strategi pembelajaran maupun, jika dimungkinkan, juga inklusif dalam bahan ajar. Jadi, ia dapat masuk dalam pembelajaran agama, kesenian, bahasa dan sastra, sejarah, matematika, dan lainlain.

Pembicaraan tentang sastra dalam kaitannya dengan pembentukan karakter, atau mungkin dikatakan pembentukan sikap dan perilaku, telah banyak dilakukan orang. Bahkan, tidak jarang timbul kesan bahwa pembelajaran sastra tidak lain adalah pembelajaran moral dan atau nilai-nilai. Hal itu tidak sepenuhnya salah, tetapi juga tidak sepenuhnya benar. Berbagai teks kesastraan diyakini mengandung unsur $\mathrm{m}$ oral dan nilai-nilai yang dapat dijadikan "bahan baku" pendidikan dan pembentukan karakter. Teks-teks kesastraan diyakini mengandung suatu "ajaran" karena tidak pengarang menulis tanpa pesan moral (messages). Na- 
mun, penekanan pada bahan tersebut bahkan tidak jarang berakibat fatal: peserta didik hanya sekadar diminta menginditifikasi moral dan nilai-nilai yang terkandung di dalam teks-teks kesastraan itu. Padahal, semestinya halhal yang bernuansa nilai luhur yang lazimnya menjadi sikap dan perilaku tokoh cerita itu adalah untuk dimengerti, direnungkan, dan diteladani dalam sikap dan perilaku hidup keseharian.

Hal itu juga berlaku dalam pembelajaran sastra anak kepada peserta didik yang notabene masih berstatus anak-anak. Pembelajaran sastra sekolah, baik di sekolah dasar dengan peserta didik yang memang masih anakanak maupun di sekolah menengah dengan peserta didik yang remaja, lazimnya menjadi bagian pembelajaran bahasa. Hal itu dapat dipahami karena sarana pengungkapan sastra adalah bahasa. Namun, harus dipahami juga bahwa sastra, baik sastra anak (children literature) maupun sastra (sastra dewasa, adult literature) lebih dari sekadar bahasa. Bahasa dalam teks kesastraan "hanyalah" merupakan aspek sarana, walau harus ada tuntutan yang berbeda untuk menjadi bahasa sastra, sedang kandungan teks itulah sebenarnya yang mengandung muatan moral dan nilainilai. Muatan inilah yang dapat dijadikan sebagai "bahan baku" pendidikan dan pembentukan karakter peserta didik lewat strategi yang paling mengena. Misalnya, membaca sastra sekaligus belajar tentang kehidupan, mengajarkan nilai-nilai luhur kehidupan tetapi peserta didik tidak merasa sedang diajari. Fokus pembicaraan di bawah ada- lah sastra anak yang dengan pangsa pembaca (pendengar) anak-anak.

\section{KITA HIDUP DIKELILINGI SASTRA}

Istilah "Kita hidup dikelilingi sastra" dipinjam dari Lakoff \& Johnson (1980) yang menulis buku Metaphors We Live by. Pada intinya, Lakoff \& Johnson menunjukkan adanya dan pentingnya metafora dalam kehidupan manusia. Dalam kehidupan sehari-hari dalam berbagai aktivitasnya, manusia tidak dapat melepaskan diri dari bermetafora, berbicara dan bahkan berpikir dengan memergunakan berbagai metafora. Misalnya, kata-kata yang sudah amat biasa didengar dalam pembicaraan sehari-hari seperti "jatuh cinta, patah hati, patah semangat, patah arang, keras kepala, berhati baja, ujian sudah di ambang pintu, gantungkan cita-cita setinggi langit, menjadi batu sandungan", dan lain-lain tidak lain adalah bentukbentuk metafora. Namun, orang tidak menyadari bahwa kata-kata yang sering diucapkan tersebut sebenarnya adalah metafora.

Berdasarkan fakta bahwa orang hampir-hampir tidak dapat menghindar dari penggunaan metafora tersebut, Lakoff \& Johnson kemudian mengatakan: kita hidup dikelilingi metafora, kita tidak bisa hidup tanpa metafora. Lebih dari itu, menurutnya bahkan metafora "menguasai" kehidupan manusia: menguasai cara berbahasa, berpikir, dan berbudaya. Sama halnya dengan kenyataan bahwa orang tidak menyadari kata-kata yang diucapkannya adalah metafora, hal sama juga terjadi dalam hal cara berpikir dan berbudaya. Artinya, kita juga tidak menyadari bah- 
wa kita sering berpikir dan berbudaya dengan bermetafora. Cobalah, misalnya, kita lihat bagaimana orang Jawa berpikir dan bersikap: sering menyampaikan sesuatu secara tidak langsung, berbicara dengan memergunakan simbol-simbol, menyembunyikan sesuatu yang sebenarnya diutamakan, dan lainlain yang sejenis, bukankah hal itu cerminan cara hidup bermetafora? Maka, sebagaimana yang pernah dilontarkan Umar Kayam, budaya Jawa penuh dengan kesombongan metafora, dan itu berimbas dengan begitu banyak ungkapan metaforis dalam bahasa Jawa.

Hal yang kurang lebih sama juga terjadi dengan sastra, khususnya sastra anak. Kita sering tidak menyadari bahwa berbagai hal dan aktivitas yang kita lakukan, atau dilakukan orang lain, juga oleh anak-anak, adalah bernuansa bersastra. Maka, tidak berlebihan jika dikatakan bahwa sebenarnya kita hidup dikelilingi sastra (anak). Ada berbagai contoh keadaan dan aktivitas yang menunjukkan kondisi dan aktivitas bersastra anak di sekeliling kehidupan keseharian kita. Dilihat dari keadaan yang demikian, sebenarnya sastra anak merupakan sesuatu yang amat kita akrabi dan sekaligus dapat dijadikan sarana strategis untuk menanam, memupuk, dan mengembangkan berbagai nilai yang ingin kita wariskan kepada anak yang bertujuan untuk pembentukan karakter. Berbagai hal dan aktivitas yang dimaksud dicontohkan di bawah ini.

- Ketika si buah hati menangis atau ketika ingin menyenangkan si buah hati, si Ibu bernyanyi-nyanyi, nembang, rengeng-rengeng, atau menina- bobokan sampai si buah hati diam dan tertawa-tawa senang.

- Ketika si buah hati membolak-balik buku dan gambar yang dipegangnya, si Ibu menunjukkan dan atau mengajari nama-nama gambar, huruf, atau angka terkait sehingga anak terlihat puas memahami.

- Ketika si buah hati menjelang tidur, si Ibu bercerita, entah cerita yang pernah didengar, dibaca, atau cerita karangan sendiri, dan entah sudah diulang berapa kali, sampai si anak tertidur membawa ceritanya ke alam mimpi dengan senyum dikulum yang amat memesona buat si Ibu.

- Ketika anak-anak TK yang bermata jernih dan menggemaskan itu ramai, ibu guru bercerita, juga entah cerita yang mana atau bagaimana atau yang ke berapa, sampai anak-anak terpana, terkagum, terbuai, atau bersorak kegirangan karena begitu antusias dan menjiwai.

Sebenarnya, apa yang dilakukan oleh si Ibu dan Bu Guru tersebut tidak lain adalah aktivitas bersastra anak. Demikian juga nyanyian, tembang-tembang dolanan, rengeng-rengeng, gamabrgambar objek atau aktivitas menarik dengan sedikit tulisan, dan cerita-cerita yang dikisahkan si lbu dan Bu guru tersebut adalah sastra anak. Itu beberapa contoh kasus bahwa sebenarnya kita, orang tua, dewasa, atau guru di sekolah sudah amat akrab dengan sastra anak dan aktivitas bersastra anak. Bahkan, jika dipikir rasanya kita "tidak dapat hidup" tanpa bersentuhan dengan sastra anak. Tetapi, mengapa sastra anak dan pembelajaran sastra anak kepada anak-anak selama ini seolah- 
olah terasa asing? Hal itu sebenarnya karena kita belum menyadari saja walau di sekeliling kita ada berbagai hal tentang sastra anak dan aktivitas yang bernuansakan sastra anak. Ketika berhubungan dengan anak-anak, entah di rumah atau di sekolah, mau tidak mau kita mesti bersentuhan dengan sastra anak, langsung atau tidak langsung. Dunia anak adalah dunia bermain, dunia menyanyi, dunia cerita, dunia bersenang-senang, dan tidak ada kesedihan sebagaimana kedihan orang dewasa di sana. Jika syair tembang-tembang dolanan dan lagu-lagu anak adalah bagian dari sastra anak, cerita yang didongengkan oleh si Ibu ketika anak menjelang tidur adalah bagian dari sastra anak, ketika mengajak dan membawa anak bersenang-senang adalah aktivitas bersastra anak, hidup keseharian kita bersama anak mau tidak mau bersentuhan dengan sastra anak. Persoalan yang dimunculkan adalah bagaimanakah memanfatkan sastra anak tersebut untuk tujuan pembentukan karakter?

Manusia hidup bermasyarakat dikelilingi oleh sastra yang notabene adalah sebagian warisan leluhur untuk menurunkan nilai-nilai kepada anakanak yang lahir kemudian. Ketika anak menonton televisi, program yang paling disukai lazimnya adalah film kartun. Ketika anak sudah bisa membaca, bacaan yang paling disukai umumnya adalah komik dan cerita. Komik yang ditampilkan lewat sarana kertas, film kartun lewat sarana televisi, dan cerita di majalah adalah juga bagian dari sastra anak. Sastra anak membentang luas sekali di sekeliling kita, baik berwujud lisan (cerita, nyanyian, finger ryme, dongeng sebelum tidur) maupun yang tertulis (cerita fiksi, cerita fantasi, cerita lama/tradisional, puisi, komik, bacaan nonfiksi, dan lain-lain). Kesemua itu dapat dimanfaatkan untuk kepentingan -sebagaimana yang menjadi fokus pembicaraan ini adalah pembentukan karakter- si buah hati kita agar kelak menjadi manusia yang berkarakter, manusia yang bermatabat. Ingat, seperti halnya kita, anak-anak pun amat butuh hiburan dan informasi untuk mengisi kehidupannya. Karena anak belum mampu memenuhi kebutuhannya sendiri, kita yang harus membantu memenuhinya dengan penuh suka, sukarela, dan bertanggungjawab. Pemenuhan kebutuhan anak itu antara lain dengan menyediakan sastra anak agar dikomsumsi oleh anak-anak.

Cakupan sastra anak membentang luas sekali, atau yang lazim dikenal sebagai genre, bahkan melebih cakupan sastra dewasa. Ia bersifat lisan, tertulis, bahkan juga aktivitas. Sastra lisan dapat berupa cerita si lbu kepada anaknya, Ibu Guru kepada murid-murid TK-nya, murid-murid SD kelas awalnya, nyanyian, tembang-tembang dolanan, rengeng-rengeng lagu ninabobo, dan lainlain. Sastra tertulis dapat berupa berbagai hal yang memang secara sengaja ditulis untuk anak dengan menekankan pentingnya unsur keindahan. Jadi, ia dapat berupa puisi, cerita fiksi, biografi tokoh, sejarah, berbagai jenis buku informasi, naskah sandiwara, dan lainlain yang lazimnya disertai gambargambar menarik. Sastra aktivitas adalah sesuatu yang berupa penampilan seperti drama, baca puisi/deklamasi, dan bahkan juga yang sekadar ber-finger 
rhyme (seperti mengetuk-ngetukkan jari di meja dengan membentuk pola irama tertentu).

Jadi, apa itu sastra anak? Sastra anak adalah citraan dan atau metafora kehidupan yang disampaikan kepada anak yang melibatkan baik aspek emosi, perasaan, pikiran, saraf sensori, maupun pengalaman moral, dan diekspresikan dalam bentuk-bentuk kebahasaan yang dapat dijangkau dan dipahami oleh pembaca anak-anak (Saxby,1991:4) Jadi, sebuah buku dapat dipandang sebagai sastra anak jika citraan dan metafora kehidupan yang dikisahkan baik dalam hal isi (emosi, perasaan, pikiran, saraf sensori, dan pengalaman moral) maupun bentuk (kebahasaan dan cara-cara pengekspresian) dapat dijangkau dan dipahami oleh anak sesuai dengan tingkat perkembangan jiwanya. Atau, children's books are books that have the child's eye at the center (Huck dkk,1987:6). Buku anak, sastra anak, adalah buku yang menempatkan sudut pandang anak sebagai pusat penceritaan.

\section{MANFAAT SASTRA: SEBUAH PRO- PAGANDA?}

Berlebihankah jika dikatakan bahwa sastra anak memunyai peran yang tidak kecil bagi usaha pembentukan karakter anak-anak?

Sejarah kehadiran sastra di masyarakat boleh dikatakan setua kehadiran masyarakat itu sendiri di dunia. Tokoh semacam Plato dan Aristoteles yang hidup kurang lebih 4-3 abad sebelum Masehi hingga sekarang masih dikenal dan dirujuk sebagai ahli kesastraan. Pengarang drama Yunani Klasik seperti Sopochles yang semasa dengan kedua tokoh tersebut -misalnya dengan karangan yang berjudul Odipus Sang Raja-juga masih memunyai gaung hingga kini. Buku-buku cerita klasik seperti Ramayana, Mahabarata, dan Kisah Seribu Satu Malam juga masih populer hingga kini. Kesemuanya itu disebutkan sekadar menunjukkan bahwa sastra telah eksis selama ribuan tahun lalu.

Pertanyaan yang menggelitik dapat dimunculkan: Mengapa? Jika tidak memunyai kemanfaatan bagi kehidupan manusia, mustahil sastra dapat "memertahankan" kelangsungan eksistensinya hingga kini. Yang pasti adalah bahwa sastra tidak lahir dalam situasi kekosongan budaya, tetapi pasti muncul pada masyarakat yang telah memiliki tradisi, adat istiadat, konvensi, keyakinan, pandangan hidup, cara hidup, cara berpikir, pandangan tentang estetika, dan lain-lain yang semuanya dapat dikategorikan sebagai wujud kebudayaan. Sastra dapat dipandang sebagai bagian integral dari kehidupan sosial budaya masyarakat yang melahirkannya. Dalam hal ini dapat dikatakan bahwa sastra muncul karena masyarakat menginginkan legitimasi kehidupan sosial budayanya, tepatnya legitimasi eksistensi kehidupannya. Walau hal tersebut tidak dapat dibenarkan semuanya dalam kehidupan dewasa ini, keadaan itu terlihat dominan menandai kehidupan masyarakat masa lampau.

Dalam kaitan manfaat sastra tampaknya hampir semua pembicara dan pecinta kesastraan suka berpromosi bahwa karya sastra mempunyai peran yang penting, yang vital, dalam dunia pendidikan. Peran sastra bagi kehidup- 
an manusia, atau aspek pragmatik kesastraan bagi kehidupan manusia, secara sederhana tetapi mengandung makna yang dalam, telah dikemukakan oleh Horatius dengan istilah sweet and usefull 'nikmat yang bermanfaat'. Sastra memberi kenikmatan kepada kita karena ia hadir untuk memberikan rasa senang, kesenangan yang menghibur yang memuaskan. Mari kita berpikir sejenak: mengapa anak-anak terpana dan kagum ketika Bu Guru bercerita dengan penuh penjiwaan, mengapa anak terbuai menjelang tidur ketika si Ibu bercerita, mengapa ibu-ibu rumah tangga begitu gandrung pada sinetron televisi? Jawabnya, karena menyenangkan bukan?, karena memberikan hiburan bukan?

Sastra memang mampu memberi kesenangan dan kenikmatan, namun di dalamnya juga terkandung "memberi kemanfaatan". Apa manfaat yang mampu diberikan oleh sastra? Jawabnya dapat dapat melibatkan berbagai aspek kehidupan yang menunjang pembentukan karakter peserta didik yang jika dituliskan dapat menghasilkan sekian tumpuk penelitian, termasuk penelitian skripsi, tesis, dan disertasi. Hal ini pula tampaknya yang menyebabkan sastra mampu bertahan dari generasi ke generasi. Sastra mengandung dan atau mencerminkan sikap hidup masyarakat di mana dan kapan karya sastra itu diciptakan. Misalnya, jika orang bermaksud meneliti berbagai perihal kehidupan orang di masa lalu, salah satu yang dapat dijadikan sumber acuan adalah sastra seperti yang berwujud folklore, folktale, folksong, cerita, hikayat, dongeng, legenda, mitos, puisi, nyanyian, dan lain-lain. Kandungan makna dari kesemuanya itulah yang dalam kaitan ini dapat dimanfaatkan sebagai salah satu sarana pembentukan karakter anak.

Pernyataan Horatius bahwa sastra bersifat sweet and useful di atas pada hakikatnya menunjukkan bahwa sastra berfung si pragmatis bagi kehidupan sosial masyarakat. Karya sastra dapat tampil dengan menawarkan alternatif model kehidupan yang diidealkan yang mencakup berbagai aspek kehidupan seperti cara berpikir, bersikap, berasa, bertindak, cara memandang dan memperlakukan sesuatu, berperi laku, dan lain-lain. Sastra dipersepsi sebagai suatu fakta sosial yang menyimpan pesan yang mampu menggerakkan emosi pembaca untuk bersikap atau berbuat sesuatu.

Sastra memunyai peran sebagai salah satu alat pendidikan yang seharusnya dimanfaatkan dalam dunia pendidikan, dan dalam penulisan ini dapat difokuskan pada peran dalam usaha untuk membentuk dan mengembangkan kepribadian anak, peran sebagai character building. Artinya, dapat sastra diyakini mempunyai andil yang tidak kecil dalam usaha pembentukan dan pengembangan kepribadian anak. Jika dimanfaatkan secara benar dan dilakukan dengan strategi yang benar pula, sastra diyakini mampu berperan dalam pengembangan manusia yang seutuhnya dengan cara yang menyenangkan. Namun, usaha pembentukan kepribadian tersebut lewat kesastraan berlangsung secara tidak langsung sebagaimana halnya pembelajaran etika, nor- 
ma-norma, agama, budi pekerti, atau yang lain. Mengapa?

Sastra bukan ajaran tentang etika dan moral walau di dalamnya terkandung perilaku etika-moral yang diidealkan sebagimana yang dimodelkan oleh tokoh cerita. Sastra bukan pelajaran agama atau budi pekerti walau di dalamnya terkandung prinsip kehidupan dan perilaku agamis sebagaimana yang diperani oleh tokoh cerita. Sastra adalah model kehidupan berbudaya dalam tindak, dalam sikap dan tingkah laku tokoh, bukan dalam konsep. Kalaupun ada konsep kehidupan yang ingin disampaikan, hal itu tidak akan diungkapkan secara langsung, melainkan "silakan pahami lewat cara berpikir, bersikap, dan berperi laku tokoh cerita". Dengan demikian, sastra sebenarnya "hanyalah" memberikan teladan kehidupan yang diidealkan, teladan kehidupan orang yang berkarakter. Teladan kehidupan untuk diteladani dalam hidup keseharian. Maka, sastra boleh dikatakan mampu menunjang pembentukan karakter anak yang masih dalam tahap perkembangan lewat teladan kehidupan tersebut.

Apakah keyakinan itu berlebihan?

Mungkin orang menganggap berlebihan jika dikatakan bahwa sastra memunyai peran penting dalam pembentukan karakter anak. Namun, sebaliknya orang juga tidak dapat menolak fakta bahwa sastra mempunyai peran dalam pembentukan karakter anak. Pengakuan bahwa sastra berperan penting itu terlihat, antara lain, dari kenyataan masa lampau hingga kini orang secara sadar mengakui eksistensi sastra, mempertahankan, menikmati, dan juga menciptakannya. Namun, mungkin ada juga orang yang hanya latah ikut-ikutan mengakui.

Bagaimanakah secara objektif? Secara teoretis sastra hadir di tengah masyarakat pastilah karena memiliki andil, manfaat, bagi kehidupan manusia. Sebagai salah satu bentuk karya seni, sastra yang notabene dihasilkan oleh individu atau komunitas tertentu, pastilah mempunyai tujuan, manfaat, memunyai sesuatu yang akan disampaikan. Ingat, disampaikan secara sastra, atau dengan cara sastra. Para pencipta karya seni, baik secara individu maupun komunitas, pastilah mempunyai keyakinan bahwa "barang" ciptaannya tidak mubazir, tidak sia-sia, ada manfaatnya bagi orang lain dan bagi komunitas masyarakat betapapun kadarnya. Kalau tidak ada keyakinan itu mustahil orang bersibuk-sibuk menghasilkan karya sastra dan mustahil pula karya sastra mampu bertahan melewati batas waktu dan zaman.

Sastra "bermain" di wilayah afektif, di ranah emosi dan perasaan tanpa mengabaikan rasio, di ranah sesuatu yang menekankan pentingnya keindahan, di ranah mataforis yang serba tidak langsung. Dilihat dari faktor ini, dengan membaca dan merenungkan nuansa makna sastra (anak), tentunya ranah-ranah yang tertuju menjadi terasah, seolah-olah terbarukan, menjadi lebih peka dan kritis. Semua anak memiliki bakat keindaha dan sastra memberi jalan untuk mengasah keindahan afektif itu, keindahan yang sekalgus berperan memerhalus emosi dan perasaan, cara bersikap, berpikir, dan berperilaku. 
Sejarah masa lalu menunjukkan bahwa karya sastra (cerita!) banyak dipergunakan sebagai sarana untuk mengajarkan berbagai keperluan hidup, memberikan ajaran moral, etika kehidupan, semangat perjuangan, mewariskan pandangan hidup, nilai-nilai yang diyakini kebenaraannya oleh masyarakat, serta memertahankan eksistensi masyarakat (bangsa). Misalnya, untuk memberikan semangat juang membela negara, para tentara kerajaan secara rutin dibacakan cerita-cerita kepahlawanan; untuk mendidik seorang putra mahkota, raja memerintahkan seorang pertapa mengajarnya dan pertapa memilih mendidik lewat cerita. Masyarakat Jawa masa lalu juga memunyai tradisi macapatan atau kegiatan bernuansakan keindahan-kesastraan-afektif yang lain yang juga berarti nguri-uri kabudayan. Jadi, apakah keyakinan bahwa sastra mempunyai peran yang tidak kecil bagi pembentukan kepribadian anak itu meragukan?

\section{SASTRA BUDAYA DALAM TINDAK}

Jika belajar dari berbagai teks kesastraan -lewat kegiatan membaca, memahami, merenungkan- kita akan menemukan fakta bahwa berbagai konsep tentang kehidupan yang berkarakter, bermatabat, yang memenuhi idealisme bertingkah laku, hampir semuanya dalam bentuk bentuk sikap dan tingkah laku. Ia dapat berupa cara bersikap, cara berpikir, cara berasa, dan cara berperilaku verbal dan nonverbal. Konsepkonsep abstrak sebagaimana yang dibicarakan dalam buku diejawantahkan dalam sikap dan perilaku tokoh cerita. Tentu saja sikap dan perilaku yang dimaksud sesuai dengan karakter yang disandangkan dan wujud sikap dan perilaku itu tergantung pengembangan alur. Jadi, belajar kehidupan lewat teksteks kesastraan tidak ubahnya belajar langsung terhadap perikehidupan masyarakat, orang per orang, kasus per kasus, dan bagaimana kesemuanya saling berinteraksi, saling menentukan, dalam sebuah sistem yang bersifat padu dan harmonis.

Dengan cara itu apakah kita akan memeroleh "sesuatu" yang bermanfaat? Jawabnya adalah tergantung, tergantung pada keseriusan, keintensifan, kepekaan dan kekritisan, serta kemauan membuka diri untuk menerima. Itulah hakikat aktivitas berapresiasi sastra. Kualitas kegiatan berapresiasi akan menentukan kualitas manfaat yang dapat diperoleh. Sebagai ilustrasi marilah kita lihat anak-anak TK ketika diasuh oleh seorang Ibu Guru. Keadaan kelas pasti ramai, teriakan sana-sini, ada yang mengganggu kawannya, ada yang menangis, dan lain-lain yang kesemuanya sebenarnya bersifat alamiah. Tetapi, bagaimanakah sikap dan reaksi si Ibu Guru? Apakah ia marah, uringuringan, biasa-biasa saja, senang, kagum, menikmati, atau yang lain adalah ditentukan oleh seberapa besar sikap dan kemampuan berapresiasinya terhadap anak-anak. Anak-anak TK di hadapannya tidak ubahnya sebuah cerita sastra yang lagi diapresiasinya.

Jika si Ibu Guru "belajar" dengan penuh kesungguhan terhadap "teks cerita sastra" yang tersaji itu, ia pasti akan memeroleh manfaat yang besar, bahkan mungkin merupakan sesuatu yang tiada diduga sebelumnya karena belajar 
langsung dari kehidupan konkret. "Perolehan" tersebut tentunya dapat dimanfaatkan dalam kehidupan karena telah menjadi bagian hidup, yaitu yang berupa sikap dan perilaku, dan yang pada giliran selanjutnya dapat dimanfatkan untuk "mengapresiasi" anak-anak TK berikutnya.

Itulah sebabnya Valdes (1986) menyebut sastra merupakan budaya dalam tindak (culture in action). Artinya, konsep sikap dan perilaku suatu budaya, suatu karakter yang mencerminkan budaya tertentu atau pandangan hidup tertentu, tidak disampaikan secara verbal dan abstrak, melainkan dalam sikap dan perilaku yang konkret sebagaimana terlihat dalam hidup keseharian. Singkatnya, sikap dan tingkah laku seseorang dalam keseharian sebenarnya mencerminkan derajat karakter dan martabatnya. Atau kalau dilihat dari sisi lain, jika mau belajar nilai-nilai, moral, karakter, atau yang lain belajarlah dari sikap dan perilaku kesehariannya yang mencerminkan kesemuanya itu. Berbagai teks kesastraan, khususnya sastra anak, menyediakan itu semua.

Secara teoretis Bloom membedakan adanya tiga ranah yang mendominasi kehidupan manusia, yaitu kognitif, afektif, dan psikomotorik. Namun, ketiga ranah itu sebenarnya tidak berada dalam kondisi terpisah dan berdiri sendiri. Sikap dan cara berpikir yang menganggap ketiganya tidak sejalan hanya menyebabkan tidak kongruennya ketiganya dalam sikap dan perilaku hidup keseharian. Misalnya, orang mengerti dengan baik bahwa membantu kesusahan orang lain itu baik, menghormati hak orang lain itu baik, tetapi keadaan itu hanya sampai pada tahap pengertian saja, dan tidak dipraktikkan dalam hidup keseharian. Hal itu berarti antara kognitif dan afektif tidak sejalan, tidak kongruen, sehingga perilaku yang tampak juga tidak baik (lihat Agustian, 2005, 2009). Dewasa ini, jika mau jujur, kita begitu banyak dihadapkan pada contoh sikap dan perilaku orang dan tokoh yang demikian. Justru dari kondisi yang demikian ini kita merasakan pentingnya pendidikan karakter kepada anak-anak Indonesia sejak mereka masih berstatus anak agar hasilnya lebih efektif. Penegasan pendidikan dan pembentuk karakter anak-anak adalah investasi sumber daya insani masa depan.

Sastra anak khususnya yang berupa cerita (fiksi, dongeng, fabel, biografi, sejarah) menampilan model kehidupan dengan mengangkat tokoh-tokoh cerita sebagai pelaku kehidupan itu. Sebagai seorang manusia tokoh-tokoh tersebut dibekali sifat, sikap, watak, dan seorang manusia biasa. Anak dapat memahami dan belajar tentang berbagai aspek kehidupan lewat apa yang diperankan oleh tokoh tersebut, termasuk berbagai motivasi yang dilatari oleh keadaan sosial budaya tokoh itu. Hubungan yang terbangun antara pembaca (anak, juga pembaca umumnya) dengan dunia cerita dalam sastra adalah hubungan personal. Pembaca masuk ke dunia cerita dan merasa menjadi bagian dalam pertarungan antartokoh. Pembaca bukan lagi sebagai seseorang yang berdiri di luar data (baca berita), melainkan menjadi data itu sendiri (Darma, 1992:88). Baik secara pikir maupun emosi, kognitif maupun afektif, pembaca ikut terbawa arus cerita sehingga baik 
penderitaan maupun kebahagiaan tokoh yang diempatinya seolah-olah menjadi penderitaan dan kebahagiaan dirinya pula. Lewat sastra daya imajinasi dan rasa estetis dapat dikembangkan.

Hal itulah antara lain yang merupakan kekuatan bacaan sastra. Karena kemampuannya menciptakan hubungan personal itu karya sastra sering dianggap jauh lebih bermakna dan menyentuh daripada masalah yang sama yang dikemukakan dengan cara lain. Membelajarkan anak tentang kedisiplinan, kejujuran, tanggung jawab, mau mengakui kesalahan, religius, dan lainlain dalam pandangan ini akan lebih efektif jika disampaikan lewat cerita dengan tokoh yang berkarakter daripada disampaikan secara langsung dan vulgar. Lewat cara pertama akan terbentuk pengertian, pemahaman, dan kemudian terjadilan proses internalisasi dalam diri anak. Anak ingin bersikap dan berperilaku sebagaimana halnya tokoh cerita yang menjadi heronya. Pada usia anak keinginan untuk selalu menirukan segala sesuatu yang dikagumi masih amat besar, dan hal ini potensial dimanfaatkan untuk pembelajaran karakter. Sebaliknya, lewat cara kedua akan lebih bersifat kognitif, diketahui dan dipahami, tetapi tidak diamalkan dalam perilaku hidup keseharian.

\section{SASTRA ANAK PENUNJANG KE- BIASAAN BERBUAT}

Seorang Ibu Guru SD kelas satu bercerita atau menyuruh anak-anak membaca sebuah cerita. Cerita anak itu berkisah tentang seorang anak nakal yang biasa mencuri mainan dan menyakiti temannya. Sudah sering di- peringatkan, tetapi ia masih saja suka melakukannya. Suatu ketika mainan dia sendiri hilang, dan karena dia menuduh kakak kelasnya yang mencuri, dia pun dihajarnya. Si anak itu menangis, tetapi kawannya tidak mau membantu bahkan tidak menunjukkan rasa simpati. Maka, anak itu pulang dengan hati yang sedih. Pelajaran apa yang dapat dipetik dari kisah singkat itu? Ibu Guru berpesan: "Makanya, anak-anak, kamu jangan suka berbuat seperti anak tersebut. Ia akan dijauhi oleh kawan-kawannya, lagipula mencuri dan menyakiti orang lain itu tidak boleh karena berdosa."

Seorang Ibu Guru yang lain bercerita atau menyuruh membaca cerita tentang dua anak yang berbeda kebiasaan. Anak yang pertama rajin membaca sehingga nilai rapornya tinggi dan berpengetahuan luas, sedang anak yang kedua malas membaca sehingga bodoh dan tidak tahu apa-apa. Ketika sekolah mengadakan lomba membaca, anak yang pertama mendapat hadiah mainan yang bagus karena dapat menjawab berbagai pertanyaan. Namun, anak yang malas tidak mendapatkan apaapa, maka ia iri dan menangis sambil pulang. Ibu Guru berpesan: "Makanya, anak-anak kamu harus rajin membaca seperti si anak rajin itu biar menjadi pintar dan mengetahui banyak hal, bahkan memeroleh hadiah yang bagus. Maukah kamu seperti anak rajin itu, anak-anak?"

Sekali lagi sastra adalah budaya dalam tindak; budaya dalam pengertian yang luas, tetapi kesemuanya mencerminkan nilai-nilai luhur yang menjanjikan sebagai manusia berkarakter 
dan bermartabat bagi yang secara ikhlas menerapkannya dan sikap hidup dan perilaku keseharian. Sastra menyajikan model kehidupan dengan tokohtokoh berkarakter yang pantas diteladani. Jika mendengar atau membaca cerita dengan menampilkan oposisi tokoh baik dan jahat, semua orang, tidak terkecuali anak-anak, akan memilih tokoh yang baik, tokoh yang menjadi hero. Kehadiran tokoh hero tersebut lengkap dengan karakternya yang mencerminkan orang yang berkarakter baik, yang mengejawantahkan nilai-nilai moral yang diidealkannya, biasanya akan ditiru dan diteladani oleh anak-anak. Mereka ingin dapat dan berkarakter seperti tokoh heronya, dan antipati kepada tokoh antagonis yang berbuat jahat yang tidak pantas ditiru.

Namun, anak-anak tidak secara otomatis mengerti itu semua. Maka, mereka harus dimengertikan, disadarkan, dilatih dan dibimbing, serta secara konkret diminta untuk menjalankan hal-hal yang baik sebagaimana dilakukan tokoh hero. Bagaimanakah cara untuk membuat mereka mengerti? Inilah kuncinya: anak-anak secara langsung dikenalkan pada cerita-cerita itu, ceritacerita yang telah dipilih oleh guru atau orang tua di rumah. Jika anak belum dapat membaca sendiri, mereka harus diceritai. Tetapi, jika sudah dapat membaca, mereka diminta untuk sering membacanya, membaca dan membaca dengan dan sekaligus dicek pemahamannya dan jangan dibiarkan tanpa kompensasi. Setiap akhir cerita Ibu Guru, si Ibu, atau orang tua perlu menegaskan kembali nilai inti yang menjadi inti cerita. Jadi, harus ada pe- nguatan yang bersifat positif. Jika anakanak masih kesulitan memahami cerita, mereka harus dilatih untuk memahami, ditunjukkan hal-hal penting, dilatih untuk menerapkannya dalam sikap dan perilaku keseharian.

Maka, kegiatan bercerita kepada anak-anak, baik di sekolah untuk anakanak TK atau SD kelas-kelas awal, maupun di rumah oleh si Ibu atau ayah, atau di tempat-tempat tertentu yang sengaja disiapkan seperti di PAUD, bercerita setiap hari adalah sebuah keharusan. Bercerita haruslah sengaja didesain menjadi sebuah rutinitas yang mesti ada dan dilakukan. Bercerita adalah sebuah ritual suci yang mesti ada dan terjaga. Kita harus menyadari hal itu dan mesti mau melakukannya. Cerita boleh apa saja, bahkan karangan kita sendiri, selama di dalamnya terkandung nilai-nilai yang membentuk kepribadian luhur. Dengan kemampuan fantasinya yang luwes, anak-anak dapat menerima cerita apa pun termasuk cerita fantasi yang menurut ukuran logika tidak masuk akal. Ingat cerita anak baik yang tersiakan dan kemudian memunyai teman baik yang adalah seorang peri, Peri Biru? Dengan cerita yang secara rutin diperolehnya, diharapkan proses internalisasi karakter yang baik sebagaimana ditunjukkan oleh para tokoh terjadi di dalam diri anak-anak.

Pengalaman yang mengesankan ketika orang masih bocah banyak yang tidak terlupakan ketika mereka telah menjadi dewasa dan bahkan sudah tua. Pengalaman menarik, bermakna, signifikan itu bahkan semakin romatis ketika diucapkan kembali ketika orang 
sudah tua. Bukankah tidak sedikit Guru Besar yang menyitir kata-kata ibubapaknya atau gurunya ketika mereka menyampaikan pidato pengukuhan di depan anggota senat? Kata-kata yang disitir itu pasti adalah kata-kata mutiara yang amat berharga dan signifikan bagi pengembangan jatidirinya dan yang diinternalisasikannya ketika bocah dan telah menjadi salah satu faktor yang menunjang keberhasilannya sebagai orang yang berkarakter, sebagai seorang Guru Besar.

Kita harus menyadari bahwa perilaku buruk lebih mudah diterima anakanak walau tanpa diajarkan. Maka, contoh-contoh sikap dan perilaku baik yang ditampilkan para tokoh cerita itu haruslah secara rutin diberikan, diajarkan, dilatihkan, namun ada juga yang dilarang untuk dilakukan, dan kesemuanya itu diamati secara terus-menerus. Di sekolah dan di rumah anakanak tidak hanya diajari apa yang harus dan boleh dilakukan, tetapi juga apa yang tidak boleh dilakukan. Semua perilaku anak-anak haruslah ada konsekuensinya yang berupa hadiah dan hukuman. Kalau seorang anak berbuat salah, ia harus menerima hukuman yang wujudnya tergantung besar-kecilnya kesalahan. Jika dibiarkan atau selalu dimaafkan, bukannya tidak mungkin hal itu juga akan diinternalisasikan oleh anak sebagai perbuatan yang sebenarnya boleh dilakukan dan itu akan terbawa sampai dewasa sebagai sikap dan perilaku.

Dewasa ini di masyarakat terlihat begitu banyak orang yang melanggar hukum, padahal kita pasti tahu bahwa mereka para pelanggar itu juga mengetahui bahwa perbuatannya itu melanggar hukum. Hal itu bukannya tidak mungkin bahwa salah satu sebabnya adalah mereka tidak dihukum ketika melakukan kesalahan ketika bocah. Jika dewasa ini banyak pencuri, pencuri berkerah putih, hal itu juga bukannya tidak mungkin ketika bocah mereka justru lebih banyak diceritai dongeng semacam Kancil Nyolong Timun -sebuah cerita yang memenangkan tokoh yang adalah pencuri (kancil!) karena kelicikannya.

Keadaan di atas menunjukkan juga bahwa pembelajaran moral baru sampai sebatas dipahami atau dimengerti secara intelektual-kognitif dan belum menjadi sikap yang menjadi bagian jiwanya yang kemudian terjelma dalam perilaku. Perbuatan dan perilaku seseorang tidak lain adalah manifestasi konkret sikapnya terhadap nilai perbuatan dan perilakunya itu. Ranah sikap, afektif, yang berada di kedalaman jiwa sana -yang oleh Agustian (2009: 42) disebut sebagai inner territory - akan menjadi motor penggerak atau sebaliknya penghalang terhadap suatu perbuatan, tergantung penilaian oleh sikap seseorang apakah perbuatan itu baik atau sebaliknya melanggar aturan. Ranah sikap yang mendorong seseorang untuk belajar, termasuk belajar nilainilai luhur, belajar untuk memahami, belajar untuk menerima, belajar untuk mencintai, dan akhirnya belajar untuk melakukannya. Jadi, faktor inilah sebenarnya yang memegang peran penting dalam kendali perilaku kehidupan.

Muara akhir pembelajaran sastra, apalagi sastra anak, dan hal ini haruslah dimengerti oleh Ibu Guru, si Ibu, 
kita, adalah afektif, adalah pembentukan kepribadian anak baik secara langsung maupun tidak langung, dan bukan kognitif. Hal itu mengisyaratkan bahwa sastra berfungsi pembentukan sikap, karakter, watak, kepribadian, karakter yang menempatkan nilai-nilai luhur dalam posisi penting dan diutamakan dalam diri pribadinya. Fungsi sastra sebenarnya lebih condong ke to move (menggerakkan emosi, sikap) daripada to teach (mengajarkan, menjelaskan), lebih condong ke ranah afektif daripada kognitif. Fungsi to move dapat diperluas dalam pengertian bersedia menerima, memahami, mengingini, mencintai, meneladani dan akhirnya dapat menyatu dengan kejiwaannya yang trefleksi dalam sikap dan perilaku keseharian. Fungsi to teach, di pihak, lebih condong berurusan dengan ranah intelektualkognitif. Namun, sayangnya pembelajaran sastra tidak jarang justru bermuara ke ranah ini, misalnya lewat hafalan-hafalan atau analisis yang keliru. Misalnya, anak-anak diminta sekadar untuk mengidentifikasi kehadiran unsur karakter dan moral dalam sebuah cerita tanpa adanya "tindak lanjut" yang menyangkut dampak afektif.

Kondisi seperti ini pulalah yang ditekankan oleh Agustian (2009:42) agar kita tidak terlalu menekankan pembelajaran intelektualistis-kognitif dan mengabaikan faktor afektif. Untuk itu, adanya self mastery dalam diri anakanak, diri kita -yang adalah semacam alat untuk menangkap sinyal-sinyal yang agung dalam hati nurani- haruslah diajarkan dan dilatihkan. Logika harus dilatihkan sehingga tidak hanya berhenti dapat berpikir kritis, melain- kan juga berperilaku kritis. Hukum tidak hanya dipelajari, tetapi harus juga diamalkan. Jika hukum hanya dipelajari saja, itu hanya akan melahirkan pengacara dan jaksa yang memainkan hukum. Hal itu berarti antara intelektualitas dan spiritualitas tidak kongruen, tidak nyambung.

Tuntutan semacam itulah yang mestinya juga terjadi dalam hal pembelajaran sastra, apalagi sastra anak untuk anak-anak: unsur intelektualitas nyambung dengan unsur sikap-spiritualitas. Sastra tidak cukup dipahami secara intelektualistis-kognitif, tetapi haruslah diusahakan untuk ditafsirkan, direnungkan, dan diteladani, atau paling tidak mampu mengubah sikap, keyakinan, atau pandangan hidup ke yang lebih baik. Pemahaman secara intelektualistis-kognitif penting, namun ia bukan merupakan tujuan akhir. Tujuan intelektualistis-kognitif sekadar sebagai jalan pembuka untuk masuk dan nyambung ke ranah afektif sehingga adanya proses pengubahan sikap pun berjalan rasional.

\section{PENUTUP}

Sastra hadir ke hadapan kita, anakanak, atau komunitas yang lain pertama-tama adalah untuk menghibur, memberikan kesenangan, sehingga setelah membacanya, atau dibacakan/ diceritakan kepada anak-anak yang belum dapat membaca, orang menjadi terpuaskan dan mengalami katarsis. Sastra bukanlah ajaran moral sebagai pelajaran agama dan budi pekerti, namun di dalamnya terdapat terdapat sikap dan perilaku moral dan etika. Pembelajaran sastra yang secara alamiah 
menyenangkan itu tidak benar jika diubah menjadi pelajaran tentang moral dan etika yang lebih condong ke intelektualistis-kognitif. Misalnya, sekadar menghafal dan mengidentifikasi kandungan unsur moral dan bukannya sikap berilaku moral sebagaaimana diperani oleh tokoh cerita. Kondisi terhibur, senang, puas, dan mengalami katarsis adalah keadaan yang lebih mencerminkan kondisi sikap, dan bukan kognitif. Kondisi yang demikian haruslah dipandang password untuk masuk ke ranah sikap pembaca yang lebih konkret, yaitu kerelaan mau merenung, menimbang-nimbang, dan meneladani yang kesemuanya bermuara pada pembentukan karakter.

Untuk itu, gerakan mau membaca, membaca apa saja yang memberi nilai tambah bagi kehidupan yang lebih baik, terutama dalam kaitan ini membaca teks-teks sastra anak, haruslah didukung dan direalisasikan dalam sikap dan perilaku konkret. Fenomena umum yang terlihat di masyarakat kita adalah adanya penyakit malas membaca. Kondisi ini juga merupakan sebuah karakter, karakter bangsa, karakter kita. Bacaan sastra yang menarik tampaknya dapat dijadikan salah satu solusi untuk mengurangi penyakit kronis itu, dan itu harus sudah mulai dilakukan dan dilatihkan secara serius kepada anakanak ketika mereka masih berstatus anak-anak. Jika menunggu sampai dewasa baru dilatihkan, ia pasti terlambat, dan hasilnya adalah pelajar, mahasiswa, dan kita semua yang tetap saja malas membaca. Membaca dianggap sebagai suatu pemborosan, dan bukannya sebuah keharusan untuk maju. Sikap dan perilaku mau membaca, kesediaan mau menyediakan waktu untuk membaca di samping seabrek aktivitas lain, kesediaan mau memandang bahwa membaca adalah penting, juga merupakan salah jenis karakter yang harus dibentuk. Usaha mulia itu harus dilakukan secara sadar dan terencana serta penyediaan fasilitas bacaan yang memadai, baik di rumah maupun di sekolah, dan salah satunya adalah sastra anak untuk anak-anak dan dewasa.

\section{UCAPAN TERIMA KASIH}

Jika kita mau jujur, sebenarnya karya yang berupa apa pun tidak pernah lepas dari peran pihak lain, baik secara langsung maupun tidak langsung, baik berupa pemikiran, dukungan moral, maupun yang lain. Demikian juga dalam hal penulisan artikel sederhana ini. Untuk itu, dengan rendah hati saya mengucapkan terima kasih atas bantuannya, kepada siapa pun yang telah membantu, baik sejawat, para penulis yang saya rujuk pemikirannya, maupun staf administrasi. Harapan saya mudah-mudahan tulisan ini ada manfatnya bagi pembaca yang membutuhkannya.

\section{DAFTAR PUSTAKA}

Agustian, Ary Ginanjar. 2005. ESQ, Emotional Spiritual Quotient. Jakarta: Arga.

Agustian, Ary Ginarjar. 2009. "Upaya Membentu Pendidikan Karakter" dalam Darmiyati Zuhdi (ed) Pendidikan Karakter, Grand Design dan Nilai-nilai Target. Yogyakarta: UNY Press, hlm 34-55. 
Darma, Budi. 1992. "Sastra dan Kebudayaan" dalam Darmiati Zuchdi \& Burhan Nurgiyantoro (ed). Seminar Nasional Bahasa dan Satra Indonesia. Yogyakarta: UPP IKIP, hlm. 87-97.

Huck, Charlotte S, Susan Hepler, dan Janet Hickman. 1987. Children's Literature in The Elementary School. New York: Holt, Rinehart and Winston.

Lakoof, George dan Mark Johnson. 1980. Methaphors We Live By. Chicago: The University of Chicago Press.
Sardiman. 2009. “Membangun Karakter Bangsa melalui Pembelajaran Sejarah" dalam Darmiyati Zuhdi (ed) Pendidikan Karakter, Grand Design dan Nilai-nilai Target. Yogyakarta: UNY Press, hlm. 71-82.

Saxbya, Maurice. 1991. "The Gift Wings: The Value of Literature to Children", dalam Maurice Saxby \& Gordon Winch (eds). Give Them Wings, The Experience of Children's Literature, Melbourne: The Macmillan Company, hlm. 3-118.

Valdes, Joyce Merril. 1986. "Culture in Literature", dalam Joyce Merril Valdes (ed), Culture Bond, Bridging the Cultural Gap in Language Teaching. Cambridge: Cambridge University Press. 